\title{
Racemic Adrenaline and Inhalation Strategies in Acute Bronchiolitis
}

\author{
Håvard Ove Skjerven, M.D., Jon Olav Gjengstø Hunderi, M.D., \\ Sabine Kristin Brügmann-Pieper, M.D., Anne Charlotte Brun, M.D., \\ Hanne Engen, M.D., Leif Eskedal, M.D., Ph.D., Marius Haavaldsen, M.D., \\ Bente Kvenshagen, M.D., Ph.D., Jon Lunde, M.D., Leif Bjarte Rolfsjord, M.D., \\ Christian Siva, M.D., Truls Vikin, M.D., Petter Mowinckel, M.Sc., \\ Kai-Håkon Carlsen, M.D., Ph.D., and Karin C. Lødrup Carlsen, M.D., Ph.D.
}

ABSTRACT

From the Department of Pediatrics, Oslo University Hospital (H.O.S., J.O.G.H., P.M., K.-H.C., K.C.L.C.), and the Institute of Clinical Medicine, University of Oslo (H.O.S., K.-H.C., K.C.L.C.), Oslo; the Department of Pediatrics, Østfold Hospital Trust, Fredrikstad, Østfold (J.O.G.H., M.H., B.K., J.L.); the Department of Pediatrics, Vestre Viken Hospital Trust, Drammen, Buskerud (S.K.B.-P.); the Department of Pediatrics, Vestfold Hospital Trust, Tønsberg, Vestfold (A.C.B., C.S.); the Department of Pediatrics, Telemark Hospital Trust, Skien, Telemark (H.E.); the Department of Pediatrics, Sørlandet Hospital Trust, Kristiansand, Vest-Agder (L.E.); and the Department of Pediatrics, Innlandet Hospital Trust, Elverum, Hedmark (L.B.R.), and Lillehammer, Oppland (T.V.) - all in Norway. Address reprint requests to Dr. Skjerven at Oslo University Hospital, Department of Pediatrics, Ullevål, Postboks 4956 Nydalen, 0424 Oslo, Norway, or at h.o.skjerven@medisin.uio.no.

N Engl J Med 2013;368:2286-93. DOI: 10.1056/NEJMoal301839

Copyright $\odot 2013$ Massachusetts Medical Society.

\section{BACKGROUND}

Acute bronchiolitis in infants frequently results in hospitalization, but there is no established consensus on inhalation therapy - either the type of medication or the frequency of administration - that may be of value. We aimed to assess the effectiveness of inhaled racemic adrenaline as compared with inhaled saline and the strategy for frequency of inhalation (on demand vs. fixed schedule) in infants hospitalized with acute bronchiolitis.

\section{METHODS}

In this eight-center, randomized, double-blind trial with a 2-by-2 factorial design, we compared inhaled racemic adrenaline with inhaled saline and on-demand inhalation with fixed-schedule inhalation (up to every 2 hours) in infants ( $<12$ months of age) with moderate-to-severe acute bronchiolitis. An overall clinical score of 4 or higher (on a scale of 0 to 10, with higher scores indicating more severe illness) was required for study inclusion. Any use of oxygen therapy, nasogastric-tube feeding, or ventilatory support was recorded. The primary outcome was the length of the hospital stay, with analyses conducted according to the intention-to-treat principle.

\section{RESULTS}

The mean age of the 404 infants included in the study was 4.2 months, and $59.4 \%$ were boys. Length of stay, use of oxygen supplementation, nasogastric-tube feeding, ventilatory support, and relative improvement in the clinical score from baseline (preinhalation) were similar in the infants treated with inhaled racemic adrenaline and those treated with inhaled saline ( $\mathrm{P}>0.1$ for all comparisons). On-demand inhalation, as compared with fixed-schedule inhalation, was associated with a significantly shorter estimated mean length of stay - 47.6 hours ( $95 \%$ confidence interval [CI], 30.6 to 64.6$)$ versus 61.3 hours $(95 \% \mathrm{CI}, 45.4$ to $77.2 ; \mathrm{P}=0.01)$ - as well as less use of oxygen supplementation (in $38.3 \%$ of infants vs. $48.7 \%, \mathrm{P}=0.04$ ), less use of ventilatory support (in $4.0 \%$ vs. $10.8 \%, \mathrm{P}=0.01)$, and fewer inhalation treatments (12.0 vs. $17.0, \mathrm{P}<0.001)$.

\section{CONCLUSIONS}

In the treatment of acute bronchiolitis in infants, inhaled racemic adrenaline is not more effective than inhaled saline. However, the strategy of inhalation on demand appears to be superior to that of inhalation on a fixed schedule. (Funded by Medicines for Children; ClinicalTrials.gov number, NCT00817466; EudraCT number, 2009-012667-34.) 
A

CUTE BRONCHIOLITIS IN INFANTS, which frequently leads to hospitalization ${ }^{1,2}$ and sometimes requires ventilatory support, is occasionally fatal ${ }^{3}$; it is usually viral in origin, with respiratory syncytial virus ${ }^{4}$ being the most common cause. The clinical disease is characterized by nasal flaring, tachypnea, dyspnea, chest retractions, crepitations, and wheezing. ${ }^{5}$

Bronchodilators are not recommended 6,7 but are often used in the treatment of bronchiolitis, ${ }^{8-10}$ as are saline inhalations. Adrenaline reduces mucosal swelling, ${ }^{11}$ giving it an edge over the $\beta_{2}$-adrenergic agonists, ${ }^{12}$ and has led to the frequent use of inhaled adrenaline, ${ }^{13}$ which has improved symptoms $s^{12,14-20}$ and reduced the need for hospitalization in outpatients with acute bronchiolitis. ${ }^{12}$ Among inpatients, however, inhaled adrenaline has not been found to reduce the length of the hospital stay. ${ }^{12,20-22}$ Assessment of the possible influences of age, sex, and status with respect to an asthma predisposition ${ }^{23}$ on the effect of inhaled adrenaline requires large multicenter studies. ${ }^{12,24}$

Inhaled nebulized solutions can be prescribed for use on demand or on a fixed schedule. We were unable to find documentation on the comparative efficacy of these two strategies in children with acute bronchiolitis.

We tested the hypothesis that inhaled racemic adrenaline is superior to inhaled saline in the treatment of acute bronchiolitis in infancy and that administration on a fixed schedule is superior to administration on demand. We also assessed whether age, sex, or status with respect to allergic diseases influenced treatment efficacy.

\section{METHODS}

\section{STUDY DESIGN}

This multicenter, double-blind, randomized clinical trial (the Bronchiolitis All-study, SE-Norway) included infants with acute bronchiolitis who were admitted to the pediatric departments of eight hospitals in southeastern Norway from January 2010 through May 2011. In accordance with a 2-by-2 factorial design, children were randomly assigned to receive inhaled racemic adrenaline or inhaled saline and to receive the assigned treatment on demand or on a fixed schedule (Fig. 1).

The study was approved by the Regional Committees for Medical and Health Research Ethics and by the Norwegian Medicines Agency and is registered in the Norwegian Biobank Registry.
Written informed consent was obtained from a parent of each child before the start of therapy. The study was audited by the Norwegian Medicines Agency in 2011. All authors vouch for the accuracy and completeness of the reported data and for the fidelity of the report to the study protocol (available with the full text of this article at NEJM.org).

The inclusion criteria were clinical signs of bronchiolitis as defined by Court ${ }^{5}$ (see the Supplementary Appendix, available at NEJM.org), an age of less than 12 months, and an overall clinical score of at least 4 on a scale of 0 to 10 . The clinical score was the sum of points allotted, from 0 (indicating normal findings) to 2 (indicating severe illness), for each of the following: general condition, skin color, findings on auscultation, respiratory rate, and retractions ${ }^{15,25}$ (Table S1 in the Supplementary Appendix). The study physicians performing the clinical scoring were trained at investigator meetings as well as on site by the first author and by local primary investigators. The exclusion criteria were the presence of any serious cardiac, immunologic, neurologic, or oncologic disease or any serious pulmonary disease other than bronchiolitis; more than one previous episode of obstructive airway disease; symptoms of disease of the lower airway (e.g., coughing) for more than 4 weeks; and receipt of any glucocorticoid therapy in the preceding 4 weeks.

Children were enrolled in the study on admission to the hospital as long as attending personnel (a physician and a nurse) were available. Clinical scoring was performed by a pediatrician. After written informed consent was obtained from a parent, children underwent randomization, and the assigned study medication was administered. The baseline characteristics of the children were obtained on admission, and the assessment included a pediatrician-guided, structured interview of one or both parents. Viral analyses of nasopharyngeal aspirates were performed at the largest hospital involved in the study (Oslo University Hospital) with the use of a polymerase-chain-reaction assay for nine common airway viruses. (See the Supplementary Appendix for further information on the biologic specimens gathered.)

Randomization was performed centrally in blocks of eight, with assignment to one of the four study groups, with the use of SAS software, version 9.3. The randomization codes were com- 


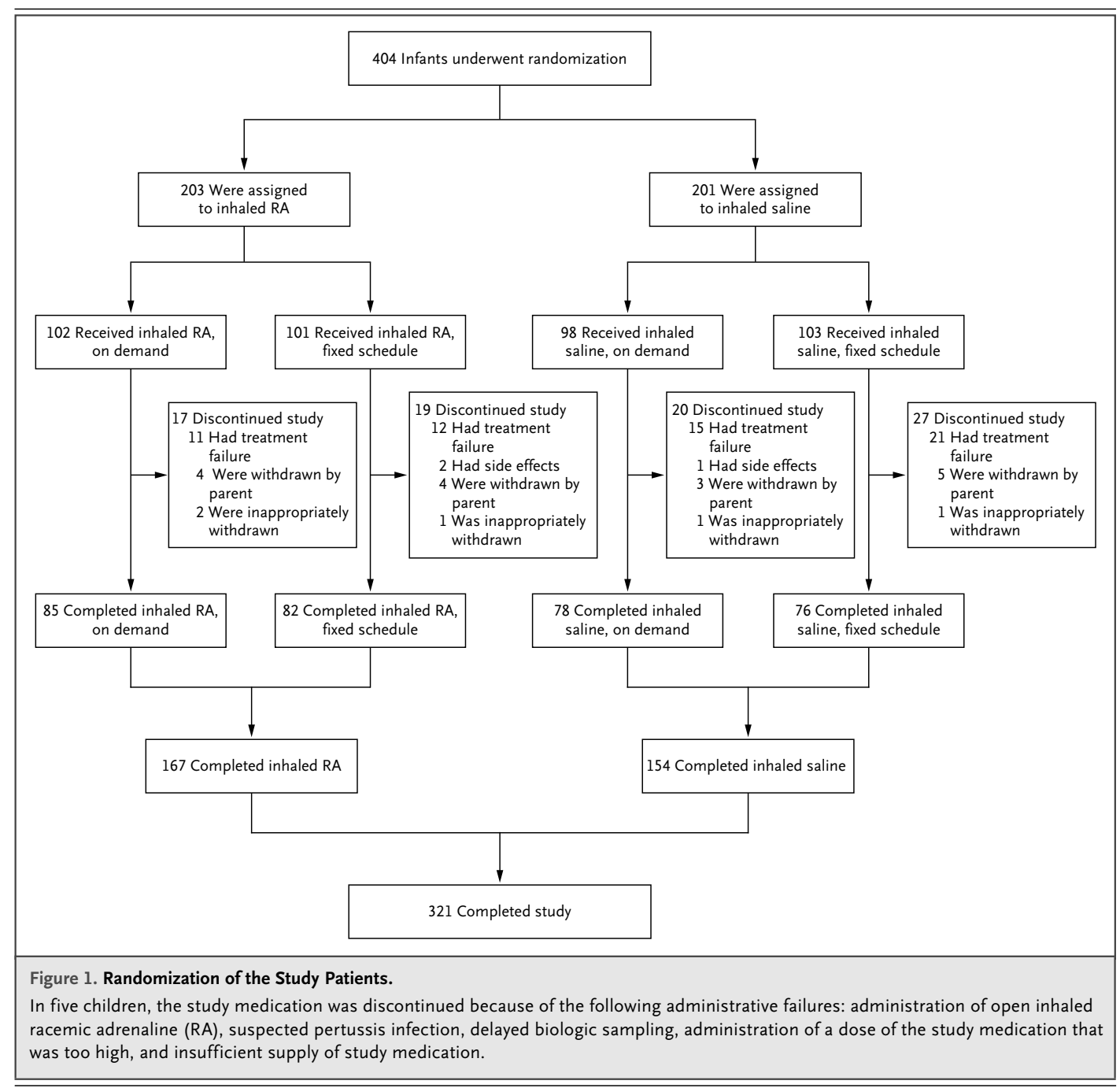

municated directly by the study statistician to the pharmacy, where doses of the two study medications $(10 \mathrm{ml}$ of racemic adrenaline dissolved in $0.9 \%$ saline to form a solution of $20 \mathrm{mg}$ per milliliter or $0.9 \%$ saline alone) were prepared in identical bottles, each labeled with a numerical code indicating the type of medication and timing of administration (on demand or fixed schedule). The study centers, which were not aware of the randomization block size, were provided with a list of study numbers for use in the consecutive assignment of medication to enrolled children.
The dose administered was based on the infant's weight: $0.10 \mathrm{ml}$ for infants weighing less than $5 \mathrm{~kg}, 0.15 \mathrm{ml}$ for those weighing 5 to $6.9 \mathrm{~kg}$, $0.20 \mathrm{ml}$ for those weighing 7 to $9.9 \mathrm{~kg}$, and $0.25 \mathrm{ml}$ for those weighing $10 \mathrm{~kg}$ or more. ${ }^{15}$ The medications were diluted in $2 \mathrm{ml}$ of saline before nebulization and were administered through a Sidestream Reusable Nebulizer with a Respironics Facemask (both from Philips Respironics), driven by $100 \%$ oxygen at a rate of 6 liters per minute. No other inhaled medications, with the exception of $0.9 \%$ inhaled saline (which was an option in both study groups, to be administered 
at the discretion of the attending physician), could be administered during the period when the infant was participating in the trial. Supportive therapy and any other treatments were provided in accordance with routine care. In accordance with national guidelines, glucocorticoids and $\beta_{2}$-adrenergic agonists were not administered. ${ }^{13}$

\section{OUTCOMES}

The primary outcome, length of hospital stay, was defined as the time from the first study inhalation until discharge from the hospital, as recorded in the medical record for each patient. Secondary outcomes were the change in the clinical score 30 minutes after the first inhalation and the use of nasogastric-tube feeding, oxygen supplementation, or ventilatory support, all of which were recorded throughout the patient's hospital stay. Adverse events during hospitalization were monitored and reported within 24 hours.

Clinical scores, oxygen saturation as measured by pulse oximetry, heart rate, respiratory rate, the use of nasogastric-tube feeding, the use of ventilatory support, and the time at which each inhalation occurred were recorded from one to four times daily during hospitalization (see the Supplementary Appendix for details). Treatment with supplemental oxygen and the performance of chest radiography were also recorded.

\section{STATISTICAL ANALYSES}

Continuous data are presented as means $( \pm S D)$, and categorical data are presented as numbers and percentages. Categorical data were assessed with the use of the Pearson chi-square test. Because data on length of stay had a non-normal distribution, comparisons between groups were assessed with the use of a robust, two-sample t-test and Huber's M-estimator, with 95\% confidence intervals.

Interactions were assessed for inhaled racemic adrenaline versus inhaled saline and on-demand versus fixed-schedule administration, as well as for treatment and site, with the use of robust linear regression and Huber's M-estimator. The Jonckheere-Terpstra test was used to assess interactions between age (at 3-month intervals) and interventions. Local regression smoothing was applied to assess the effect of age on length of stay.

The power analysis was based on the length of stay of approximately 450 children hospitalized at the main study site during a 12-month period before the start of the study. Assuming that clinically relevant improvement would be indicated by a length of stay that was reduced by at least 5 hours in the group receiving inhaled racemic adrenaline, ${ }^{26}$ we calculated that a total of 176 children in each medication group would provide a power of at least $80 \%$ at a two-sided alpha level of 0.05 . Owing to the inclusion of secondary outcomes and subgroup analyses, we increased the enrollment target to a total of 500 children. The level of significance was set at 0.05 , and analyses were performed with the use of SAS software, version 9.3, and IBM SPSS software, version 19.

\section{RESULTS}

\section{STUDY PATIENTS}

The study included 404 children $(59.4 \%$ of whom were boys) with a mean age of 126 days (4.2 months) (Table 1). The number of children enrolled at each study center ranged from 22 to 136 (mean, 51) (Table S2 in the Supplementary Appendix). The study medication was discontinued in 83 children (20.5\%) for the reasons listed in Figure 1.

The mean $( \pm S D)$ length of stay for all infants was $80 \pm 67$ hours; most children were discharged between 8 a.m. and 11 p.m. (Fig. S1 in the Supplementary Appendix). Baseline characteristics did not differ significantly among the four study groups (Table 1).

Routine respiratory viral assays were performed in 123 of the 136 children admitted to Oslo University Hospital; 99 of those 123 children $(80.5 \%)$ were positive for respiratory syncytial virus and 21 of 123 children (17.1\%) were positive for another virus; 5 of 123 (4.1\%) children were positive for two viruses.

\section{RACEMIC ADRENALINE VERSUS SALINE}

There was no significant difference in length of hospital stay between children treated with inhaled racemic adrenaline and those treated with inhaled saline $(\mathrm{P}=0.43)$ (Table 2 and Fig. 2A). There were also no significant between-group differences in the use of nasogastric-tube feeding, supplemental oxygen, or ventilatory support; clinical scores before and after the first inhalation of the study medication; or the number of children in whom the study medication was discontinued (36 children in the group receiving inhaled racemic adrenaline and 47 in the group receiving inhaled saline) (Table 2). 


\begin{tabular}{|c|c|c|c|c|}
\hline \multirow[t]{2}{*}{ Characteristics } & \multicolumn{2}{|c|}{ Inhaled Racemic Adrenaline } & \multicolumn{2}{|c|}{ Inhaled Saline } \\
\hline & $\begin{array}{l}\text { On Demand } \\
(\mathrm{N}=102)\end{array}$ & $\begin{array}{c}\text { Fixed } \\
\text { Schedule } \\
(N=101)\end{array}$ & $\begin{array}{l}\text { On Demand } \\
(\mathrm{N}=98)\end{array}$ & $\begin{array}{c}\text { Fixed } \\
\text { Schedule } \\
(N=103)\end{array}$ \\
\hline Male sex - no. (\%) & $63(61.8)$ & $60(59.4)$ & $54(55.1)$ & $63(61.2)$ \\
\hline Mean age - days & $134.9 \pm 91.6$ & $116.9 \pm 87.8$ & $117.8 \pm 68.1$ & $136.0 \pm 97.0$ \\
\hline \multicolumn{5}{|l|}{ Parental race — no./total no. (\%) $\dagger$} \\
\hline Father white & $79 / 87(90.8)$ & $85 / 90(94.4)$ & $75 / 83(90.4)$ & $83 / 91(91.2)$ \\
\hline Mother white & $79 / 88(89.8)$ & $85 / 92(92.4)$ & $78 / 84$ (92.9) & $83 / 92(90.2)$ \\
\hline \multicolumn{5}{|l|}{ Medical history - no./total no. (\%) } \\
\hline Atopic eczema & $12 / 92(13.0)$ & $8 / 96(8.3)$ & $6 / 90(6.6)$ & $14 / 96(14.6)$ \\
\hline Allergies & $4 / 87(4.6)$ & $0 / 96(0)$ & $1 / 90(1.1)$ & $2 / 96(2.1)$ \\
\hline 1 previous wheeze & $24 / 88(27.3)$ & $23 / 91(25.3)$ & $20 / 90(22.2)$ & $31 / 93(33.3)$ \\
\hline Respiratory symptoms for $>1 \mathrm{wk}$ - no./total no. (\%) & $8 / 75(10.7)$ & $12 / 90(13.3)$ & $10 / 86(11.6)$ & $15 / 89(16.9)$ \\
\hline \multicolumn{5}{|l|}{ Parental medical history — no./total no. (\%) } \\
\hline Asthma & $17 / 78(21.8)$ & $22 / 83(26.5)$ & $23 / 80(28.8)$ & $21 / 84(25.0)$ \\
\hline Rhinoconjunctivitis & $23 / 88(26.1)$ & $33 / 89(37.1)$ & $23 / 87(26.4)$ & $34 / 92(37.0)$ \\
\hline \multicolumn{5}{|l|}{ Clinical characteristics before study inclusion } \\
\hline Clinical scoret & $4.9 \pm 1.0$ & $5.0 \pm 1.0$ & $4.9 \pm 1.0$ & $4.9 \pm 1.0$ \\
\hline $\mathrm{SpO}_{2} \sqrt{\mathrm{J}}$ & $96.0 \pm 3.6$ & $96.0 \pm 3.3$ & $96.0 \pm 3.4$ & $96.1 \pm 2.8$ \\
\hline Respiratory rate - breaths/min & $53.1 \pm 11.8$ & $53.6 \pm 10.5$ & $53.8 \pm 11.3$ & $53.4 \pm 11.1$ \\
\hline Heart rate - beats/min & $154.5 \pm 17.5$ & $156.0 \pm 18.7$ & $155.2 \pm 19.9$ & $153.7 \pm 17.7$ \\
\hline \multicolumn{5}{|c|}{$\begin{array}{l}\text { Plus-minus values are means } \pm \text { SD. No significant differences in baseline characteristics were found among the four } \\
\text { groups. } \\
\text { Race was determined by the investigator. } \\
\text { A clinical score of } 4 \text { or higher (on a range of } 0 \text { to } 10 \text {, with } 0 \text { being the best score) was required for study inclusion. } \\
\mathrm{SpO}_{2} \text { denotes oxygen saturation as measured by pulse oximetry. }\end{array}$} \\
\hline
\end{tabular}

\section{ON-DEMAND VERSUS FIXED-SCHEDULE ADMINISTRATION}

The mean length of the hospital stay was significantly shorter for children in the group receiving treatment on demand than in the group receiving treatment on a fixed schedule $(\mathrm{P}=0.01)$ (Table 2 and Fig. 2B). Children in the on-demand group received a mean of 5.0 (30\%) fewer inhalations than those in the fixed-schedule group $(\mathrm{P}<0.001)$. Children receiving inhalations on demand also had a lower probability of being treated with ventilatory support $(\mathrm{P}=0.01)$ or supplemental oxygen $(\mathrm{P}=0.04)$, and inhalations given on demand were not associated with nasogastric-tube feeding or treatment discontinuation (Table 2).

There was no interaction between the two treatment interventions (inhaled racemic adrenaline vs. inhaled saline and on-demand vs. fixed schedule), with an estimated interaction term of 1.4 hours $(95 \%$ confidence interval [CI], -20.1 to
22.8; $\mathrm{P}=0.90$ ) (Table $\mathrm{S} 4$ in the Supplementary Appendix.)

\section{INFLUENCE Of AGE, ALlergic disease, AND SEX}

Age (in 3-month periods) had a significant effect on length of hospital stay with regard to both medication type and inhalation strategy, as estimated with the use of the Jonckheere-Terpstra test $(\mathrm{P}<0.001)$. The stay was longer in the younger infants ( $<8$ weeks of age) than in the older infants ( $\geq 8$ weeks of age) in the group receiving inhaled racemic adrenaline group, as indicated with a curve showing the median at every time point (Fig. S2A and S2B in the Supplementary Appendix).

In subgroup analyses comparing children younger than 3 months of age $(177$, or $43.8 \%$ of the study population) with those 3 months of age or older, there was no significant difference between the effect of inhaled racemic adrenaline 


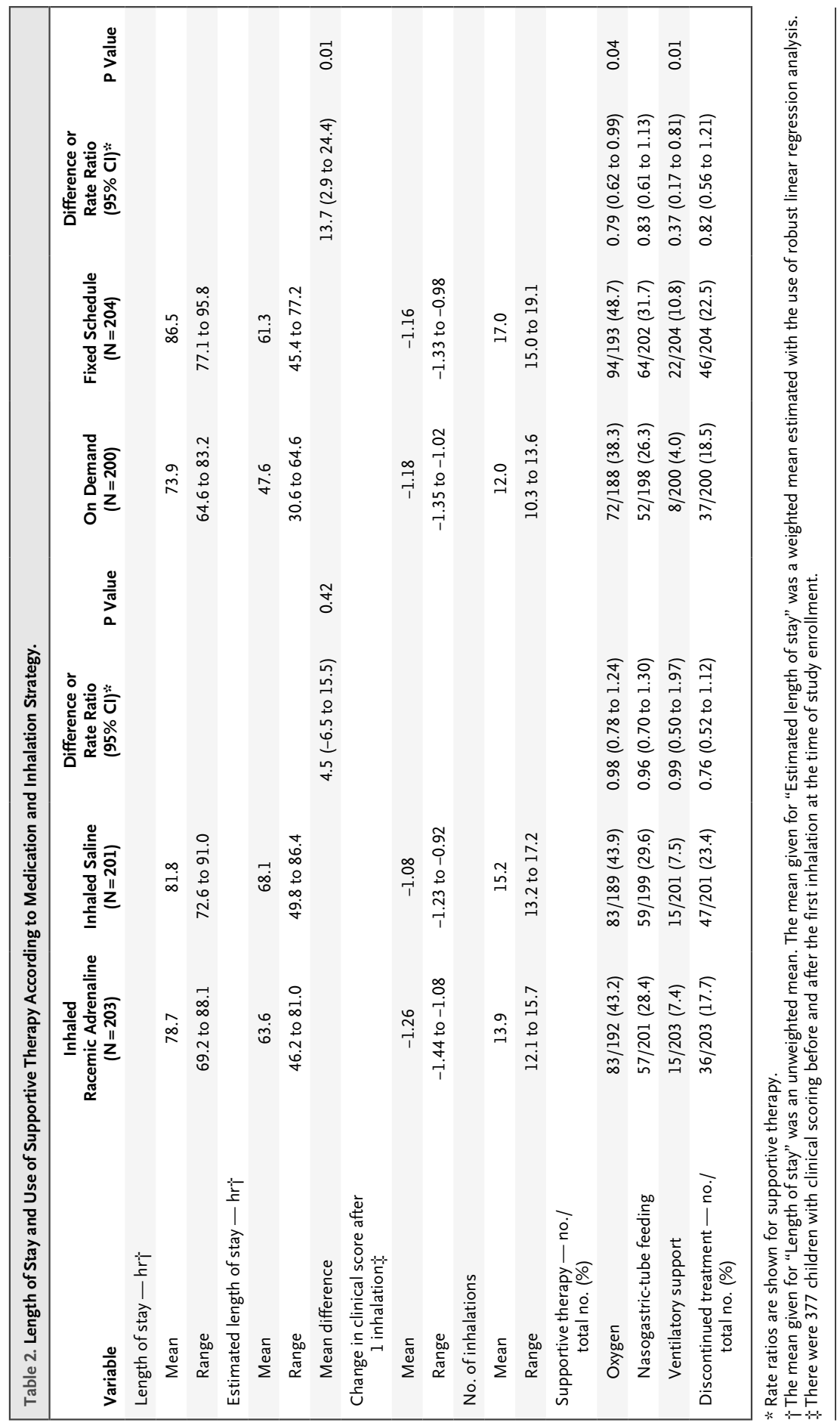

N ENGLJ MED 368;24 NEJM.ORG JUNE 13, 2013 


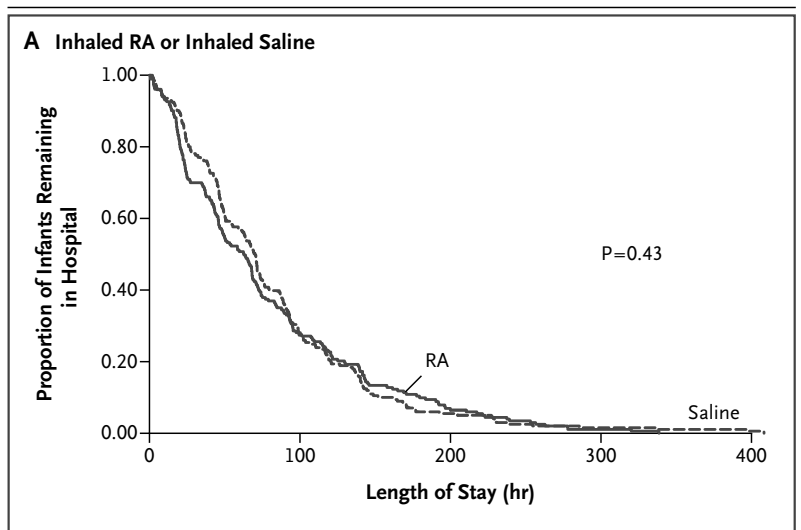

B On Demand vs. Fixed Schedule

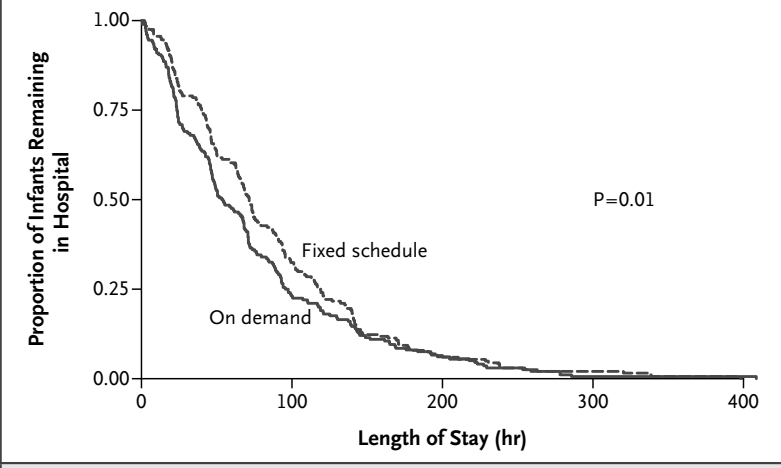

Figure 2. Length of Hospital Stay According to Study Treatment and Schedule of Administration.

Kaplan-Meier plots show the proportion of infants remaining in the hospital according to whether they were treated with inhaled racemic adrenaline or inhaled saline (Panel A) and according to whether the inhalations were administered on demand or on a fixed schedule (Panel B).

as compared with that of inhaled saline. In the youngest children only, inhalations given on demand were associated with a significantly shorter hospital stay than were inhalations given on a fixed schedule (Table S3 in the Supplementary Appendix). Status with respect to a history of atopic eczema or wheezing, status with respect to a family history of atopic disease, and sex were not found to have a significant influence on treatment response.

\section{ADVERSE EVENTS}

No serious adverse events were reported. Three children (including one who was receiving inhaled saline) discontinued treatment because of moderate tachycardia, which may have been due to the study medication.

\section{DISCUSSION}

In infants with acute bronchiolitis, treatment with inhalations of racemic adrenaline was not associated with a shorter hospital stay than treatment with inhaled saline. However, the administration of inhalations on demand was found to be superior to administration on a fixed schedule in reducing the length of stay and in reducing the use of ventilatory support, supplemental oxygen therapy, and nasogastric-tube feeding. There was an interaction between age and either medication type or inhalation strategy.

The lack of effect of inhaled racemic adrenaline on length of hospital stay confirms similar findings on length of stay for albuterol and saline $^{21}$ and for albuterol alone. ${ }^{22}$ There was a similar lack of effect of these medications on the clinical score and oxygen saturation according to a Cochrane meta-analysis, ${ }^{12}$ including the findings in 292 patients from two trials ${ }^{20,21}$ reviewed in the meta-analysis.

Our data show that inhalations given on demand are superior to those administered on a fixed schedule in children younger than 12 months of age, with the mean length of stay 13.7 hours shorter for those receiving inhalations on demand. This difference was both clinically and statistically significant and has substantial financial implications. Although not previously shown, the possibility that saline may have a bronchoconstrictive effect in the youngest infants (younger than 3 months of age) cannot be ruled out. Thus, the superiority of the on-demand schedule, in which fewer inhalations were administered, supports the goal of "minimal handling" (allowing infants to sleep, with minimal interruption ${ }^{27}$ in acutely ill infants.

The significant interaction we noted between age and inhaled racemic adrenaline is of interest. The tendency for the youngest infants receiving inhaled racemic adrenaline to have a longer hospital stay does not support the reported effectiveness of inhaled racemic adrenaline for reducing vascular engorgement and edema in children with asthma. ${ }^{11}$ Also unlike the findings in children with asthma, ${ }^{28}$ in our study population of children with bronchiolitis, status with respect to a parental history of allergic disease, status with respect to atopic eczema, and sex were not associated with symptomatic treatment efficacy.

Our study of two inhalation solutions was sufficiently powered to allow detection of a 
5-hour difference in length of stay and to perform subgroup analyses for the major outcomes. The study included a nationally representative patient cohort with the expected patterns of viral infection. ${ }^{4}$ In addition, the study was managed in accordance with local and national guidelines, and the baseline characteristics were similar in all four treatment groups (Table S1 in the Supplementary Appendix).

Despite the limited power of the study to detect an interaction between the interventions, the observed interaction was approximately one third of the 5-hour length of stay selected a priori as a clinically relevant difference. ${ }^{26}$ The initially planned end point for length of stay, which was the time at which the child was deemed ready for discharge, was not recorded for 83 children (Fig. 1). We therefore used the actual time of dis- charge for all children. The results were similar with the use of these two end points (Table S5 in the Supplementary Appendix).

In conclusion, our study showed that for hospitalized infants with acute bronchiolitis, inhaled racemic adrenaline was not superior to inhaled saline with regard to length of hospital stay, use of supportive treatment, or clinical score. However, the administration of inhalations on demand, as compared with a fixed schedule of inhalations, was associated with a shorter hospital stay and with a reduced need for supportive treatment.

Supported by Medicines for Children, a publicly funded body administered by Haukeland University Hospital.

Disclosure forms provided by the authors are available with the full text of this article at NEJM.org.

We thank the nurses and pediatricians at all the participating hospitals for their invaluable contribution to this project.

\section{REFERENCES}

1. Stockman LJ, Curns AT, Anderson LJ, Fischer-Langley G. Respiratory syncytial virus-associated hospitalizations among infants and young children in the United States, 1997-2006. Pediatr Infect Dis J 2012;31:5-9.

2. Leader S, Kohlhase K. Respiratory syncytial virus-coded pediatric hospitalizations, 1997 to 1999 . Pediatr Infect Dis J 2002;21:629-32.

3. Donlan M, Fontela PS, Puligandla PS. Use of continuous positive airway pressure (CPAP) in acute viral bronchiolitis: a systematic review. Pediatr Pulmonol 2011;46:736-46.

4. Mansbach JM, McAdam AJ, Clark S, et al. Prospective multicenter study of the viral etiology of bronchiolitis in the emergency department. Acad Emerg Med 2008; 15:111-8.

5. Court SD. The definition of acute respiratory illnesses in children. Postgrad Med J 1973;49:771-6.

6. American Academy of Pediatrics Subcommittee on Diagnosis and Management of Bronchiolitis. Diagnosis and management of bronchiolitis. Pediatrics 2006; 118:1774-93.

7. Baumer JH. SIGN guideline on bronchiolitis in infants. Arch Dis Child Educ Pract Ed 2007;92(5):ep149-ep151.

8. Law BJ, De Carvalho V. Respiratory syncytial virus infections in hospitalized Canadian children: regional differences in patient populations and management practices. Pediatr Infect Dis J 1993;12:65963.

9. Newcomb RW. Use of adrenergic bronchodilators by pediatric allergists and pulmonologists. Am J Dis Child 1989;143: 481-5.

10. Kimpen JL, Schaad UB. Treatment of respiratory syncytial virus bronchiolitis:
1995 poll of members of the European Society for Paediatric Infectious Diseases. Pediatr Infect Dis J 1997;16:479-81.

11. Wohl ME, Chernick V. State of the art: bronchiolitis. Am Rev Respir Dis 1978;118: 759-81.

12. Hartling L, Bialy LM, Vandermeer B, et al. Epinephrine for bronchiolitis. Cochrane Database Syst Rev 2011;6:CD003123.

13. Pettersen $M H$, Halvorsen $T$, Carlsen KH. Akutt bronkiolitt. Veileder i akutt pediatri. Oslo: Den norske lægeforening, 2007:198-201. (In Norwegian.)

14. Hariprakash S, Alexander J, Carroll W, et al. Randomized controlled trial of nebulized adrenaline in acute bronchiolitis. Pediatr Allergy Immunol 2003;14:134-9. 15. Kristjánsson S, Lødrup Carlsen $\mathrm{KC}$, Wennergren G, Strannegard IL, Carlsen $\mathrm{KH}$. Nebulised racemic adrenaline in the treatment of acute bronchiolitis in infants and toddlers. Arch Dis Child 1993;69:650-4. 16. Lødrup Carlsen KC, Carlsen KH. Inhaled nebulized adrenaline improves lung function in infants with acute bronchiolitis. Respir Med 2000;94:709-14.

17. Menon K, Sutcliffe T, Klassen TP. A randomized trial comparing the efficacy of epinephrine with salbutamol in the treatment of acute bronchiolitis. J Pediatr 1995; 126:1004-7.

18. Reijonen T, Korppi M, Pitkäkangas S, Tenhola S, Remes K. The clinical efficacy of nebulized racemic epinephrine and albuterol in acute bronchiolitis. Arch Pediatr Adolesc Med 1995;149:686-92.

19. Sanchez I, De Koster J, Powell RE, Wolstein R, Chernick V. Effect of racemic epinephrine and salbutamol on clinical score and pulmonary mechanics in infants with bronchiolitis. J Pediatr 1993; 122:145-51.

20. Wainwright C, Altamirano L, Cheney
$\mathrm{M}$, et al. A multicenter, randomized, double-blind, controlled trial of nebulized epinephrine in infants with acute bronchiolitis. N Engl J Med 2003;349:27-35. 21. Patel H, Platt RW, Pekeles GS, Ducharme FM. A randomized, controlled trial of the effectiveness of nebulized therapy with epinephrine compared with albuterol and saline in infants hospitalized for acute viral bronchiolitis. J Pediatr 2002;141:818-24.

22. Langley JM, Smith MB, LeBlanc JC, Joudrey H, Ojah CR, Pianosi P. Racemic epinephrine compared to salbutamol in hospitalized young children with bronchiolitis; a randomized controlled clinical trial. BMC Pediatr 2005;5:7.

23. Sigurs N, Gustafsson PM, Bjarnason $\mathrm{R}$, et al. Severe respiratory syncytial virus bronchiolitis in infancy and asthma and allergy at age 13. Am J Respir Crit Care Med 2005;171:137-41.

24. Smyth RL, Openshaw PJ. Bronchiolitis. Lancet 2006;368:312-22.

25. Wennergren G, Engström I, Bjure J. Transcutaneous oxygen and carbon dioxide levels and a clinical symptom scale for monitoring the acute asthmatic state in infants and young children. Acta Paediatr Scand 1986;75:465-9.

26. Panickar J, Lakhanpaul M, Lambert PC, et al. Oral prednisolone for preschool children with acute virus-induced wheezing. N Engl J Med 2009;360:329-38.

27. Murdoch DR, Darlow BA. Handling during neonatal intensive care. Arch Dis Child 1984;59:957-61.

28. Bacharier LB, Boner A, Carlsen $\mathrm{KH}$, et al. Diagnosis and treatment of asthma in childhood: a PRACTALL consensus report. Allergy 2008;63:5-34. [Erratum, Allergy 2008;63:630.]

Copyright (c) 2013 Massachusetts Medical Society. 


\section{Supplementary Appendix}

This appendix has been provided by the authors to give readers additional information about their work.

Supplement to: Skjerven HO, Hunderi JOG, Brügmann-Pieper SK, et al. Racemic adrenaline and inhalation strategies in acute bronchiolitis. N Engl J Med 2013;368:2286-93. DOI: 10.1056/NEJMoa1301839 


\section{Supplementary Appendix}

\section{Racemic Adrenaline and Inhalation Strategies in Acute Bronchiolitis}

(Bronchiolitis All-study SE Norway, ClincialTrials.gov number, NCT00817466. EudraCT number, 2009-012667-34)

A study performed within the ORAACLE, Oslo, Norway

Håvard Ove Skjerven ${ }^{1,2}$; Jon Olav Gjengstø Hunderi ${ }^{3,2}$, Sabine Kristin Brügmann-Pieper ${ }^{4}$, Anne

Charlotte Brun ${ }^{5}$, Hanne Engen ${ }^{6}$, Leif Eskedal ${ }^{7}$, Marius Haavaldsen ${ }^{3}$, Bente Kvenshagen ${ }^{3}$, Jon

Lunde $^{3}$, Leif Bjarte Rolfsjord ${ }^{8}$, Christian Siva ${ }^{5}$, Truls Vikin ${ }^{9}$, Petter Mowinckel ${ }^{2}$, Kai-Håkon

Carlsen $^{1,2}$, Karin C. Lødrup Carlsen ${ }^{2,1}$

1. Institute of Clinical Medicine, University of Oslo, Oslo, Norway

2. Dept of Paediatrics, Oslo University Hospital, Oslo, Norway

3. Dept of Paediatrics, Østfold Hospital Trust, Fredrikstad, Østfold, Norway

4. Dept of Paediatrics, Vestre Viken Hospital Trust, Drammen, Buskerud, Norway

5. Dept of Paediatrics, Vestfold Hospital Trust, Tønsberg, Vestfold, Norway

6. Dept of Paediatrics, Telemark Hospital Trust, Skien, Telemark, Norway

7. Dept of Paediatrics, Sørlandet Hospital Trust, Kristiansand, Vest-Agder, Norway

8. Dept of Paediatrics, Innlandet Hospital Trust, Elverum, Hedmark, Norway

9. Dept of Paediatrics, Innlandet Hospital Trust, Lillehammer, Oppland, Norway

The study was performed within ORAACLE (the Oslo Research Group of Asthma and Allergy in Childhood; the Lung and Environment), a member of GA ${ }^{2}$ LEN (Global Asthma and Allergy European Network) and MeDALL (Mechanisms of the Development of ALLergy) a collaborative project conducted within the European Union under the Health Cooperation Work Programme of the 7th Framework programme (grant agreement No. 261357) 
Corresponding author: Håvard Ove Skjerven

\section{Address:}

Oslo University Hospital

Dept of Pediatrics, Ullevål

Postboks 4956 Nydalen

0424 Oslo

Email: h.o.skjerven@medisin.uio.no 


\section{Table of Contents}

- Page 3 Introduction

- Page 3 Methods

- Clinical scoring

- Clinical registrations and management

- Page $5 \quad$ Results

- Influence of Age

- Page 5 Discussion

- Pages 6-10 Table S1, S2, S3, S4 and S5

- Page 11 References and Figure Legends

- Pages 12-15 Figure S1 and Figures S2a and S2b 


\section{Introduction}

Length of stay in bronchiolitis is mostly influenced by supportive treatment ${ }^{1}$ such as nasogastric feeding and oxygen supplementation and less commonly by ventilatory support ${ }^{2,3}$

\section{Methods}

\section{Clinical scoring}

Acute bronchiolitis was defined by Court as following:

"Illness mainly affecting infants, especially in the first 6 months of life. Rapid respiration, dyspnea, wheezing, chest recession, cough, rhonchi and rales are very frequent. Visible distension of the chest and increased pulmonary translucency on the chest radiograph are frequent and of high diagnostic significance. Upper respiratory features, especially nasal discharge and a red pharynx are frequent. Fever is very frequent, but high fever is uncommon.”

Very frequent is noted as at least $50 \%$ of the children, while frequent refers to $25-50 \%$.

\section{Clinical registrations and management}

The clinical score (Table S1) was recorded by a physician prior to and 30 minutes after an inhalation every morning. Parents and the attending nurse each completed a visual analogue scale (VAS) and the nurse noted oxygen saturation, respiratory rates and heart rates prior to and 30 minutes after the first inhalation and subsequently once every morning and evening. Saliva was sampled upon inclusion and in the first morning, and nasopharyngeal aspirates and urinary samples were collected as soon as possible after inclusion. All stored biological samples were frozen within 24 hours for further analysis. Biological samples, nurse and parental VAS scale as well as clinical scoring by physician throughout the hospital stay will not be further discussed in the present paper. 
Registration of the use of nasogastric tube feeding and ventilatory support and time for each inhalation were recorded daily.

\section{Results}

\section{Influence of age}

In children younger than three months only, inhalations given OD compared to RI was associated with a relative risk of $0.37(0.15-0.90)$ of patients receiving treatment with ventilatory support $(\mathrm{p}=0.021)$. (Table S3)

\section{Discussion}

The clinical scoring (Table S1) used in the present study had previously been used in a

Scandinavian study ${ }^{4}$, but was, in line with other scoring systems of acute bronchiolitis, not

validated ${ }^{5}$. The commonly used Respiratory Distress Assessment Instrument ${ }^{6}$ was considered to be too specific.

In contrast to most other studies, this study allowed inclusion of patients with one previous episode of wheeze. Subgroup analyses of patients with no previous wheeze (n=264) showed similar results of the main outcome (LOS) as the total population (Table S3). 
Table S1: Clinical score

\begin{tabular}{|l|l|l|l|}
\hline & Score 0 & Score 1 & Score 2 \\
\hline $\begin{array}{l}\text { Respiratory rate } \\
\text { (breaths/ min) }\end{array}$ & $<40$ & $40-60$ & $>60$ \\
\hline $\begin{array}{l}\text { Respiratory chest } \\
\text { recessions }\end{array}$ & None & $\begin{array}{l}\text { Moderate } \\
\text { Costodiaphragmatic }\end{array}$ & $\begin{array}{l}\text { Severe } \\
\text { As 1, +rib and jugular } \\
\text { retraction }\end{array}$ \\
\hline $\begin{array}{l}\text { Auscultatory } \\
\text { breath sounds }\end{array}$ & Vesicular & $\begin{array}{l}\text { Wheeze }+ \\
\text { rales/ronchi }\end{array}$ & $\begin{array}{l}\text { Faint } \pm \text { severe wheeze } \pm \\
\text { pronounced rales and } \\
\text { ronchi }\end{array}$ \\
\hline Skin colour & Normal & Pallor & Cyanosis \\
\hline General condition & Not affected & Moderately affected & Severely affected \\
\hline
\end{tabular}


Table S2: Randomization by hospital

\begin{tabular}{|l|l|l|l|l|l|}
\hline Hospital & iRA & iS & OD & RI & Total \\
\hline Oslo University Hospital & 67 & 69 & 66 & 70 & 136 \\
\hline Østfold Hospital HF & 52 & 48 & 49 & 51 & 100 \\
\hline Vestre Viken Hospital HF & 15 & 13 & 14 & 14 & 28 \\
\hline Vestfold Hospital HF & 17 & 19 & 17 & 19 & 38 \\
\hline Sykehuset Innlandet Lillehammer HF & 11 & 12 & 14 & 9 & 23 \\
\hline Sykehuset Innlandet Elverum HF & 15 & 13 & 14 & 14 & 28 \\
\hline Sørlandet Sykehus HF & 10 & 12 & 12 & 10 & 22 \\
\hline Sykehuset Telemark HF & 16 & 15 & 14 & 17 & 31 \\
\hline
\end{tabular}


Table S3: Length of Stay in subgroup analysis

\begin{tabular}{|c|c|c|c|c|}
\hline 1 previous wheeze & Adrenaline & Saline & On demand & Fixed schedule \\
\hline $\mathrm{N}$ & 47 & 51 & 44 & 54 \\
\hline Mean LOS, hours & 78.1 & 88.6 & 85.0 & 82.4 \\
\hline Estimated mean LOS*, hours (95\% CI) & 74.2 & 72.0 & 60.8 & 66.4 \\
\hline $\begin{array}{l}\text { Mean difference in estimated mean LOS* (95\% } \\
\text { confidence interval) }\end{array}$ & \multicolumn{2}{|c|}{$-2.2(-26.8,22.3) \mathrm{p}=0.86$} & \multicolumn{2}{|c|}{$5.6(-18.8,30.0) \mathrm{p}=0.65$} \\
\hline \multicolumn{5}{|l|}{ No previous wheeze } \\
\hline $\mathrm{N}$ & 132 & 132 & 134 & 130 \\
\hline Mean LOS, hours & 81.7 & 81.2 & 72.9 & 90.3 \\
\hline Estimated mean LOS*, hours (95\% CI) & 56.3 & 64.5 & 47.6 & 62.5 \\
\hline $\begin{array}{l}\text { Mean difference in estimated mean LOS* (95\% } \\
\text { confidence interval) }\end{array}$ & \multicolumn{2}{|c|}{$8.3(-4.8,21.3) \mathrm{p}=0.22$} & \multicolumn{2}{|c|}{$14.9(1.81,28.0) \mathbf{p}=\mathbf{0 . 0 3}$} \\
\hline \multicolumn{5}{|l|}{ Age $<3$ months } \\
\hline $\mathrm{N}$ & 92 & 85 & 86 & 91 \\
\hline Mean LOS, hours & 100.9 & 91.4 & 83.5 & 108.5 \\
\hline Estimated mean LOS*, hours (95\% CI) & 93.1 & 89.2 & 41.3 & 71.6 \\
\hline $\begin{array}{l}\text { Mean difference in estimated mean LOS* (95\% } \\
\text { confidence interval) }\end{array}$ & \multicolumn{2}{|c|}{$-3.8(-24.7,17.0) \mathrm{p}=0.72$} & \multicolumn{2}{|c|}{$30.3(10.3,50.3) \mathbf{p}=\mathbf{0 . 0 0 3}$} \\
\hline \multicolumn{5}{|l|}{ Age $>3$ months } \\
\hline $\mathrm{N}$ & 111 & 116 & 114 & 113 \\
\hline Mean LOS, hours & 60.2 & 74.8 & 66.7 & 68.7 \\
\hline Estimated mean LOS*, hours (95\% CI) & 50.7 & 55.9 & 52.8 & 56.6 \\
\hline $\begin{array}{l}\text { Mean difference in estimated mean LOS* ( } 95 \% \\
\text { confidence interval) }\end{array}$ & \multicolumn{2}{|c|}{$5.2(-6.7,17.0) \mathrm{p}=0.39$} & \multicolumn{2}{|c|}{$3.8(-8.0,15.6) \mathrm{p}=0.53$} \\
\hline
\end{tabular}

*Length of Stay (LOS) estimated by robust linear regression analyses. 
Table S4: Results by all randomization groups

\begin{tabular}{|c|c|c|c|c|}
\hline & $\begin{array}{r}\text { Adrenaline/ } \\
\text { On demand } \\
(\mathbf{N}=102)\end{array}$ & $\begin{array}{r}\text { Adrenaline } \\
\text { / Fixed } \\
\text { Schedule } \\
(\mathrm{N}=101)\end{array}$ & $\begin{array}{r}\text { Saline/ On } \\
\text { Demand } \\
(\mathrm{N}=98)\end{array}$ & $\begin{array}{r}\text { Saline/ Fixed } \\
\text { Schedule } \\
(N=103)\end{array}$ \\
\hline $\begin{array}{l}\text { Mean Length of Stay in hours (95\% } \\
\text { confidence intervals) }\end{array}$ & $71.6(58.9-84.2)$ & $85.9(72.0-99.7)$ & 76.3 (62.9-89.8) & $87.0(74.5-99.6)$ \\
\hline $\begin{array}{l}\text { Change in clinical score by } 1 \text {. Inhalations } \\
\text { (95\% confidence intervals) }\end{array}$ & $\begin{array}{r}-1.22(-1.45 \\
\text { to }-0.98)\end{array}$ & $\begin{array}{r}-1.31(-1.37 \text { to } \\
0.93)\end{array}$ & $\begin{array}{r}-1.15(-1.37 \\
\text { to }-0.93)\end{array}$ & $\begin{array}{r}-1.01(-1.22 \text { to }- \\
0.80)\end{array}$ \\
\hline \multicolumn{5}{|c|}{ Use for supportive therapy no/total no. (\%) } \\
\hline Oxygen & 37/96 (38.5) & 46/96 (47.9) & 35/92 (38.0) & 48/97 (49.5) \\
\hline Nasogastric Tube Feeding & 28/101 (27.7) & $29 / 100(29.0)$ & 24/97 (24.7) & $35 / 102(34.3)$ \\
\hline Ventilatory Support & $2 / 102(2.0)$ & 13/101 (12.9) & $6 / 98(6.1)$ & 9/103 (8.7) \\
\hline Discontinued treatment & 17/102 (16.7) & 19/101 (18.8) & $\begin{array}{l}20 / 98 \\
(20.4)\end{array}$ & 27/103 (26.2) \\
\hline
\end{tabular}


Skjerven

Table S5: Mean Length of Stay (LOS) for children not discontinued (n=321).

$\begin{array}{lrrrr} & \begin{array}{r}\text { Adrenaline/ } \\ \text { On demand } \\ \mathbf{( N = 8 5 )}\end{array} & \begin{array}{r}\text { Adrenaline/ } \\ \text { Fixed Schedule } \\ \mathbf{( N = 8 2 )}\end{array} & \begin{array}{r}\text { Saline/ } \\ \text { On Demand } \\ \mathbf{( N = 7 8 )}\end{array} & \begin{array}{r}\text { Saline/ } \\ \text { Fixed Schedule } \\ (\mathbf{N}=\mathbf{7 6})\end{array} \\ \text { ITT: Mean LOS (hr) } & 57.5(46.8-68.3) & 69.4(57.6-81.3) & 59.5(49.5-70.0) & 76.4(65.5-87.3) \\ \text { PP: Mean LOS } & 54.7(44.4-65.0) & 64.0(53.3-74.7) & 54.8(45.1-64.5) & 72.8(62.0-86.6)\end{array}$

\begin{tabular}{|c|c|c|c|c|}
\hline & $\begin{array}{r}\text { Adrenaline } \\
(\mathrm{N}=167)\end{array}$ & $\begin{array}{r}\text { Saline } \\
(\mathrm{N}=154)\end{array}$ & $\begin{array}{r}\text { On Demand } \\
(\mathrm{N}=163)\end{array}$ & $\begin{array}{r}\text { Fixed Schedule } \\
(\mathrm{N}=158)\end{array}$ \\
\hline $\begin{array}{l}\text { Mean LOS actual discharge, hours } \\
(95 \% \text { CI })\end{array}$ & $63.4(55.3-71.4)$ & $67.9(60.3-75.4)$ & $58.5(51.1-65.9)$ & $72.8(64.7-80.9)$ \\
\hline $\begin{array}{l}\text { Mean LOS, deemed ready for } \\
\text { discharge, hours ( } 95 \% \text { CI) }\end{array}$ & $59.3(51.8-66.7)$ & $63.7(56.3-71.0)$ & $54.7(47.6-61.8)$ & $68.2(60.6-75.8)$ \\
\hline $\begin{array}{l}\text { Estimated mean LOS*, actual } \\
\text { discharge, hours }(95 \% \mathrm{CI})\end{array}$ & $47.4(31.4-63.4)$ & $55.0(39.9-70.1)$ & $37.1(21.1-53.0)$ & $51.5(35.3-67.7)$ \\
\hline $\begin{array}{l}\text { Mean difference in estimated mean } \\
\text { LOS*, actual discharge }\end{array}$ & \multicolumn{2}{|c|}{$7.60(-2.64$ to 17.8$), p=0.15$} & \multicolumn{2}{|c|}{14.4 (4.3 to 24.6$), \mathbf{p}=\mathbf{0 . 0 1}$} \\
\hline $\begin{array}{l}\text { Estimated mean LOS*, deemed ready } \\
\text { for discharge, hours }(95 \% \mathrm{CI})\end{array}$ & $47.1(31.6-62.6)$ & $52.7(45.4-58.9)$ & $33.6(18.2-49.1)$ & $48.3(39.3-57.3)$ \\
\hline Mean difference in estimated mean & \multirow{2}{*}{\multicolumn{2}{|c|}{$5.6(-4.4$ to 15.5$), p=0.27$}} & \multicolumn{2}{|c|}{14.7 (4.9 to 24.5 ), $\mathbf{p}=\mathbf{0 . 0 0 4}$} \\
\hline LOS*, deemed ready for discharge & & & & \\
\hline Mean number of inhalations (95\% CI) & $15.1(13.0-17.2)$ & $17.2(14.8-19.6)$ & $12.8(10.9-14.6)$ & $19.5(17.0-22.0)$ \\
\hline
\end{tabular}

Pearsons correlation coefficient between actual time of discharge and deemed ready for discharge was calculated to 0.99 . * Length of Stay (LOS) estimated by robust linear regression analyses. 


\section{Figure legends:}

Figure S1: Discharge from hospital in number per hour of the day in children treated with bronchiolitis by randomization groups A (adrenaline/on demand), B (adrenaline/fixed schedule), C (saline/on demand) and D (saline/fixed schedule).

Figure S2: Length of Stay given by age for treatment medication with inhaled racemic adrenaline versus inhaled saline (A) and treatment strategy on demand versus fixed schedule (B) in infants with acute bronchiolitis. Regression lines are calculated by local regression smoothing, with 95\% confidence interval shaded in gray for each of the smoothing lines.

\section{References}

1. Cunningham S, McMurray A. Observational study of two oxygen saturation targets for discharge in bronchiolitis. Archives of disease in childhood 2012;97:361-3.

2. Donlan M, Fontela PS, Puligandla PS. Use of continuous positive airway pressure (CPAP) in acute viral bronchiolitis: a systematic review. PediatrPulmonol 2011;46:736-46.

3. Wang EE, Law BJ, Stephens D. Pediatric Investigators Collaborative Network on Infections in Canada (PICNIC) prospective study of risk factors and outcomes in patients hospitalized with respiratory syncytial viral lower respiratory tract infection. The Journal of pediatrics 1995;126:212-9.

4. Kristjansson S, Lodrup Carlsen KC, Wennergren G, Strannegard IL, Carlsen KH. Nebulised racemic adrenaline in the treatment of acute bronchiolitis in infants and toddlers. ArchDisChild 1993;69:650-4.

5. McCallum GB, Morris PS, Wilson CC, et al. Severity scoring systems: Are they internally valid, reliable and predictive of oxygen use in children with acute bronchiolitis? Pediatric pulmonology 2012.

6. Lowell DI, Lister G, Von Koss H, McCarthy P. Wheezing in infants: the response to epinephrine. Pediatrics 1987;79:939-45. 
Figure S1a

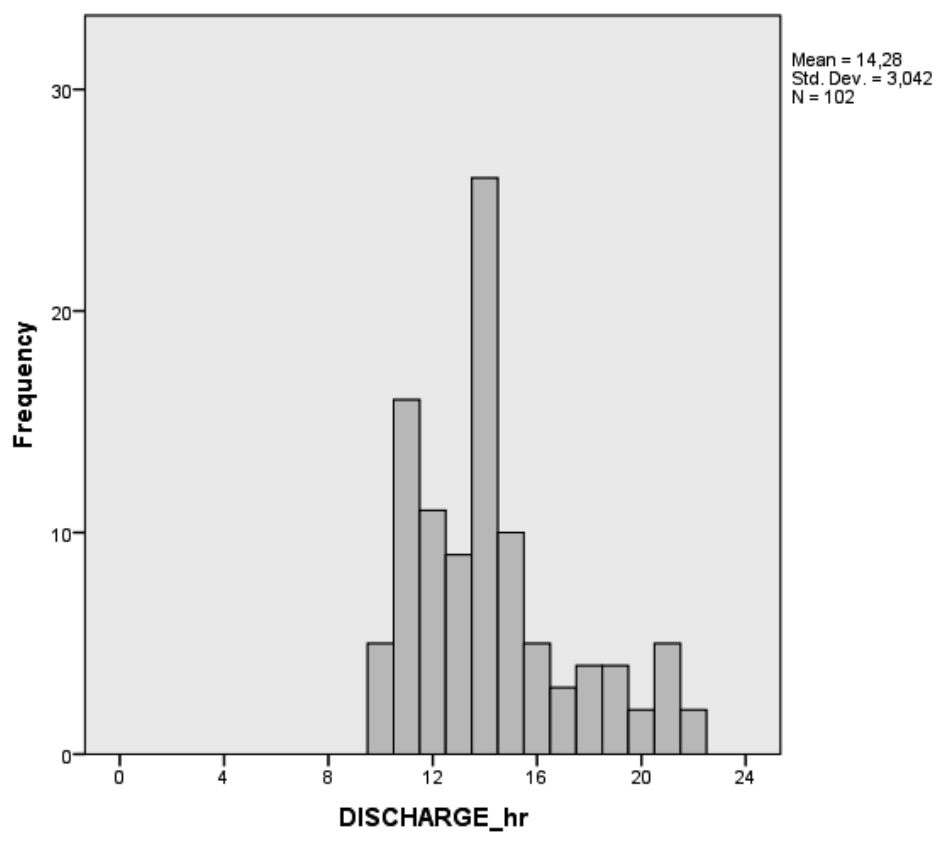

Figure S1b

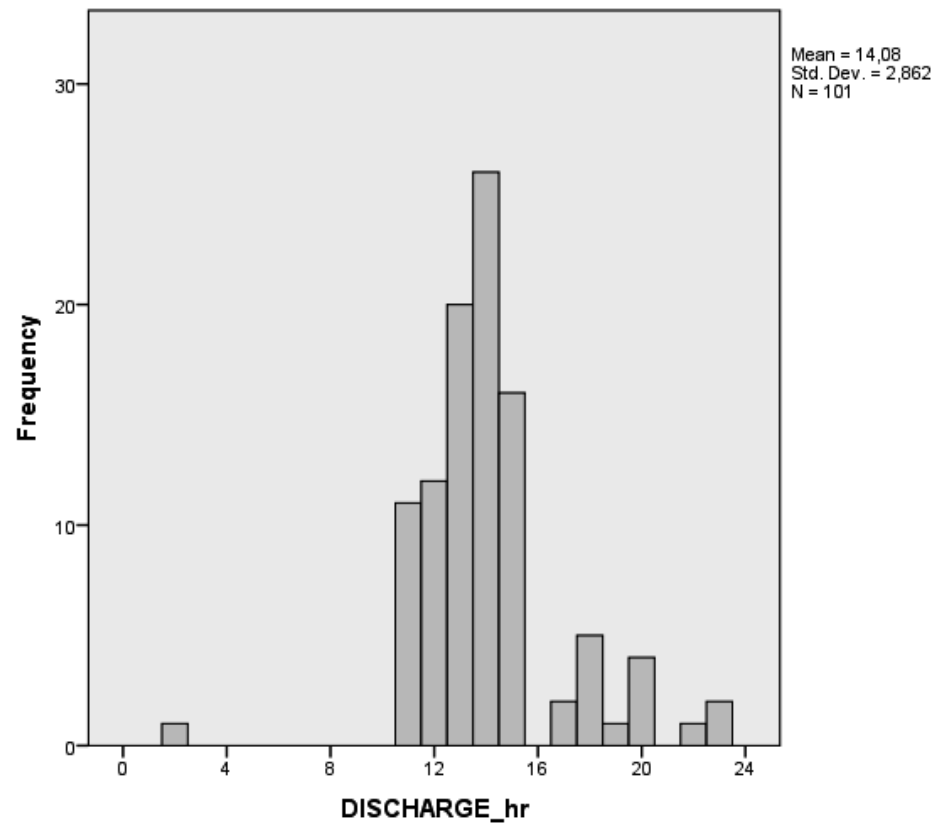


Figure S1c

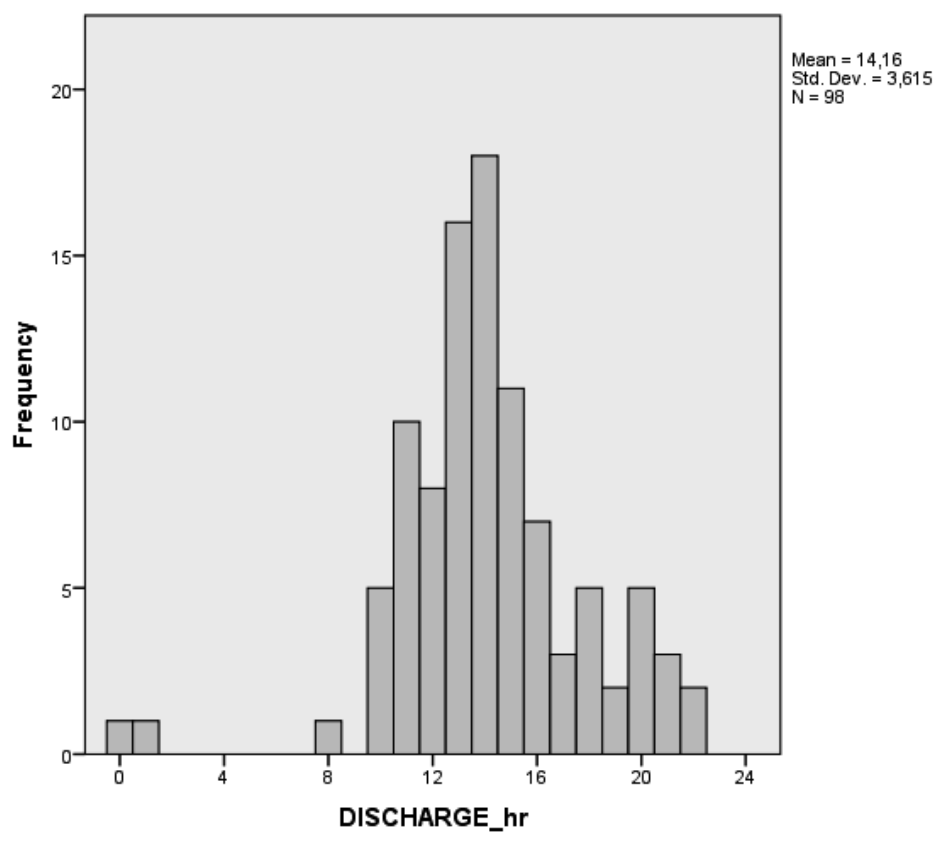

Figure S1d

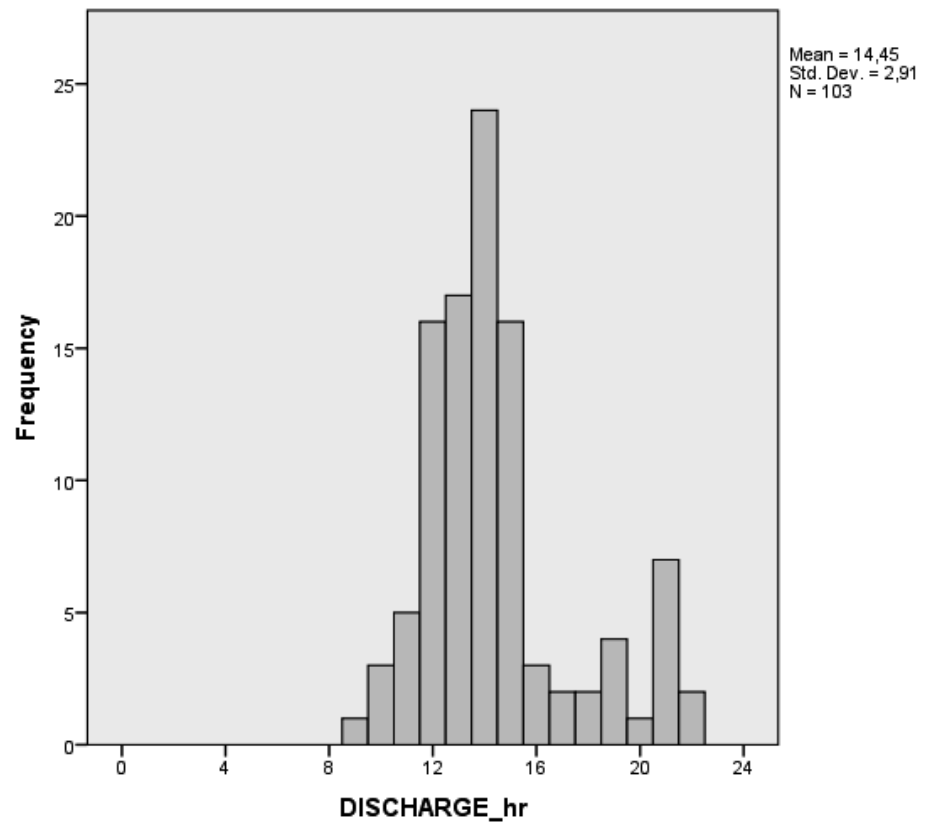


Figure S2a

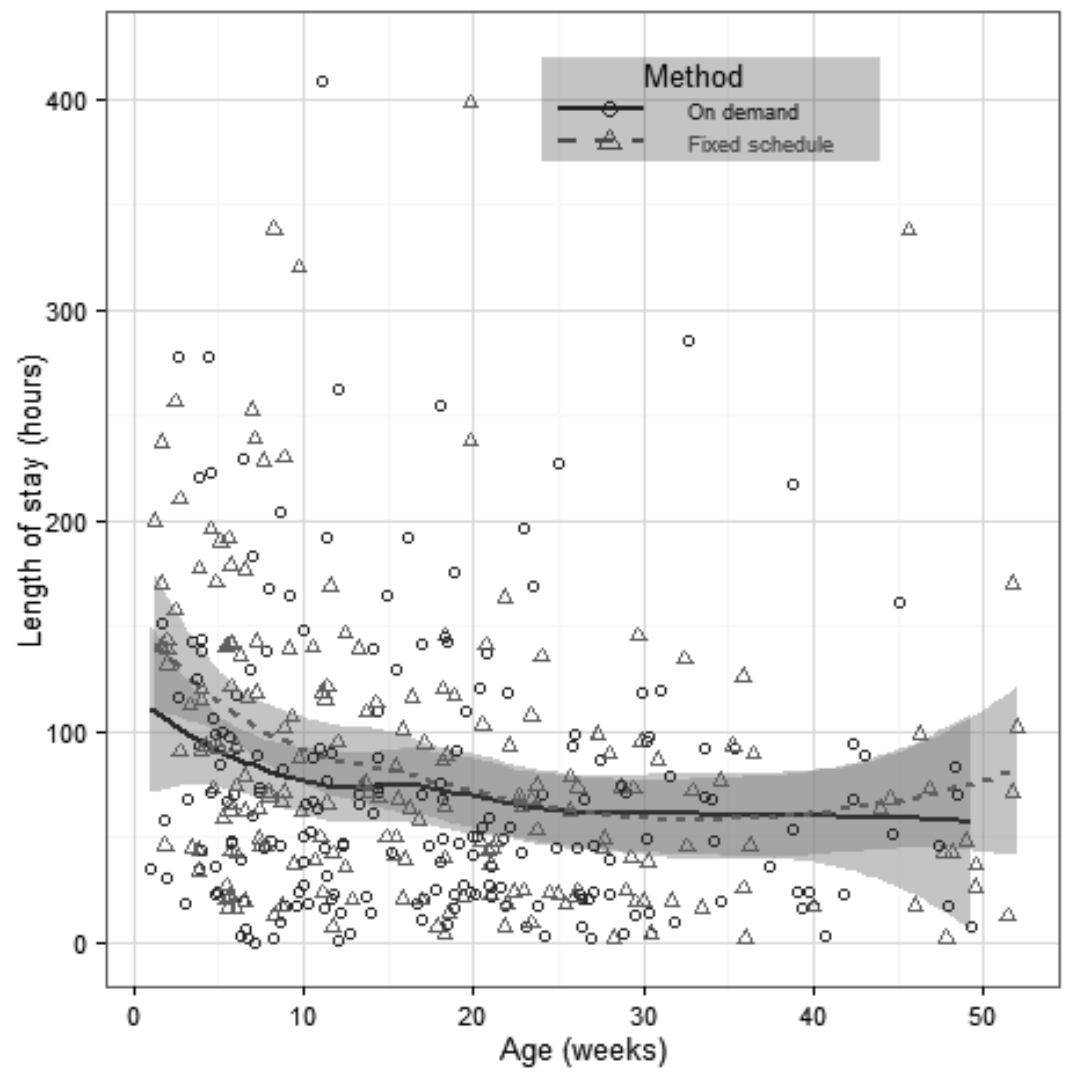


Figure $S 2 b$

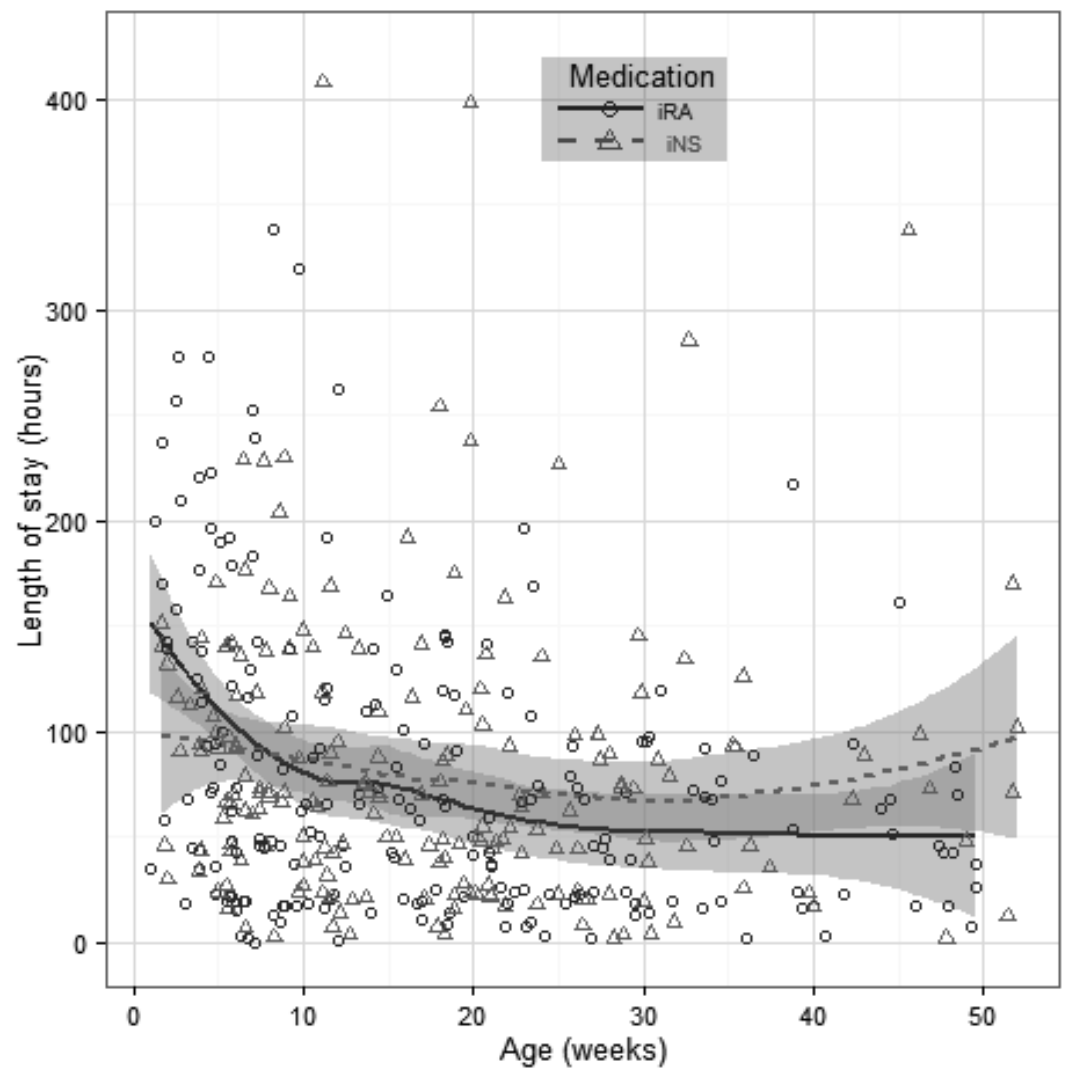


TO THE EDITOR: Kerlin and colleagues report no significant effect of in-hospital nighttime intensivists on patient outcomes. The authors suggest that the findings might be explained by the high quality of care provided by well-trained residents with telephone access to attending physicians. Given that resident training hours are limited, ${ }^{1}$ did the telephone interactions preclude an important training opportunity? The presence of nighttime attending physicians allows increased contact between residents and attending physicians. It also improves the educational experience, as noted in this study and others. ${ }^{2}$ In future studies evaluating the role of in-hospital nighttime attending physicians, the role of resident education should be considered.

Kumaran Shanmugarajah, M.R.C.S.
Imperial College London
London, United Kingdom
kshanmugarajah@partners.org
Maria Lucia Madariaga, M.D.
Massachusetts General Hospital
Boston, MA
Sebastian Michel, M.D.
Ludwig-Maximilians-Universität
Munich, Germany
No potential conflict of interest relevant to this letter was re-
ported.
1. Steinbrook R. The debate over residents' work hours. N Engl
J Med 2002;347:1296-302.
2. Haber LA, Lau CY, Sharpe BA, Arora VM, Farnan JM, Ranji
SR. Effects of increased overnight supervision on resident educa-
tion, decision-making, and autonomy. J Hosp Med 2012;7:606-10.
Dol: 10.1056/NEJMc1308523

THE AUTHORS REPLY: We agree with Li and colleagues that family satisfaction is an important outcome, although it was not measured in this study. As noted in the Discussion section of our article, future studies of intensivist staffing should consider measuring family and nurse satisfaction.

In response to David's point: we defined nighttime admissions as admissions of patients who arrived in the medical ICU between 5 p.m. and 4:59 a.m., since these patients were routinely examined completely by the nighttime intensivists when they were present, rather than the daytime team. Although the findings were not included in the article, we conducted a sensitivity analysis using David's definition of nighttime admissions and found results identical to those that we reported.

We also agree with the comment by Shanmugarajah and colleagues regarding the possible opportunity for education during nighttime hours with the presence of a nighttime intensivist. We believe there are uncertain benefits of autonomy versus supervised instruction for trainees and long-term implications for the intensivist workforce $^{1}$ that warrant further study to inform policies on nighttime staffing.

Meeta Prasad Kerlin, M.D., M.S.C.E.

Scott D. Halpern, M.D., Ph.D.

Perelman School of Medicine at the University of Pennsylvania Philadelphia, PA

shalpern@exchange.upenn.edu

Since publication of their article, the authors report no further potential conflict of interest.

1. Kerlin MP, Halpern SD. Twenty-four-hour intensivist staffing in teaching hospitals: tensions between safety today and safety tomorrow. Chest 2012;141:1315-20.

DOI: 10.1056/NEJMc1308523

\section{Inhaled Adrenaline in Acute Bronchiolitis}

TO THE EDITOR: Skjerven and colleagues (June 13 issue ${ }^{1}$ reported that inhaled racemic adrenaline is not more effective than inhaled saline in infants with acute bronchiolitis. Inhaled therapies are used frequently to treat children with bronchiolitis, ${ }^{2}$ despite the lack of evidence from clinical trials and recommendations against their use. ${ }^{3}$ The American Academy of Pediatrics recommendations for bronchiolitis state, "A carefully monitored trial of $\alpha$-adrenergic or $\beta$-adrenergic medication is an option. Inhaled bronchodilators should be continued only if there is a document- ed positive clinical response to the trial using an objective means of evaluation." ${ }^{3}$ We wonder whether the authors could identify a subgroup of infants who had a better initial clinical response to adrenaline (e.g., improvement in the overall clinical score of $>2$ ) and whether these participants had better clinical outcomes than did the overall population studied.

Ricardo G. Branco, M.D., Ph.D.

Addenbrooke's Hospital

Cambridge, United Kingdom

rgb35@medschl.cam.ac.uk 
Pedro Celiny R. Garcia, M.D., Ph.D.

Hospital São Lucas da PUCRS

Porto Alegre, Brazil

Robert C. Tasker, M.D.

Harvard Medical School

Boston, MA

No potential conflict of interest relevant to this letter was reported.

1. Skjerven HO, Hunderi JO, Brügmann-Pieper SK, et al. Racemic adrenaline and inhalation strategies in acute bronchiolitis. N Engl J Med 2013;368:2286-93.

2. Johnson LW, Robles J, Hudgins A, Osburn S, Martin D, Thompson A. Management of bronchiolitis in the emergency department: impact of evidence-based guidelines? Pediatrics 2013;131:Suppl 1:S103-S109.

3. Harris JA, Huskins WC, Langley JM, Siegel JD. Health care epidemiology perspective on the October 2006 recommendations of the Subcommittee on Diagnosis and Management of Bronchiolitis. Pediatrics 2007;120:890-2.

DOI: 10.1056/NEJMc1308964

TO THE EDITOR: The study by Skjerven et al. showed that on-demand inhalation of racemic adrenaline or saline, as compared with fixedschedule inhalation, shortens mean length of hospital stay and decreases the need for supplemental oxygen in infants with bronchiolitis. However, the authors do not define what criteria were used to implement on-demand treatment. Because one of the main objectives was to compare the clinical effectiveness of the two above approaches, the definition of "on demand" should be clearly delineated. Moreover, the authors should define the criteria used for infant discharge and state whether or not the same criteria were applied in all participating hospitals. These criteria, which are based on oxygen saturation and the respiratory effort observed during feeding, vary between the United States and Europe, ${ }^{1-3}$ but they should be clearly specified.

Jesús Ruiz-Contreras, Ph.D.

Luis Ignacio Gonzalez-Granado, M.D.

Hospital 12 Octubre

Madrid, Spain

jruizcontreras@gmail.com

No potential conflict of interest relevant to this letter was reported.

1. Wainwright $\mathrm{C}$, Altamirano L, Cheney M, et al. A multicenter, randomized, double-blind, controlled trial of nebulized epinephrine in infants with acute bronchiolitis. N Engl J Med 2003;349: 27-35.

2. Evidence-based care guideline for infants with bronchiolitis. Cincinnati: Cincinnati Children's Hospital Medical Center, 2010 (http://www.cincinnatichildrens.org/assets/0/78/1067/2709/2777/ 2793/9199/edf8f194-1a56-48f7-8419-7c5e0a168b5d.pdf).

3. Bronchiolitis in children: a national clinical guideline. Edinburgh: Scottish Intercollegiate Guidelines Network, 2006 (http:// www.sign.ac.uk/pdf/sign91.pdf).

DOI: 10.1056/NEJMc1308964
THE AUTHORS REPLY: Branco et al. asked if a subgroup of infants had a better initial clinical response to adrenaline, defined as an improvement in the overall clinical score of more than 2 (on a scale of 0 to 10 , with higher scores indicating more severe disease; the overall score includes subscores for general condition, skin color, findings on auscultation, respiratory rate, and retractions). In fact, we assessed a similar improvement, defined as a $25 \%$ improvement in the clinical score or a higher category of oxygen saturation ( $<92 \%, 92$ to $95 \%$, or $>95 \%$ ), in an analysis in which infants were categorized as either having a response or not having a response. We found similar numbers of infants with a response in the adrenaline and saline groups (64\% in each group) and no significant difference in the length of hospital stay between infants who had a response and those who did not. A similar analysis using an improvement in the clinical score of more than 2 as the outcome did not influence the results substantially. The youngest infants ( $<8$ weeks of age), however, had longer hospital stays than older infants in the group receiving racemic adrenaline, as indicated in a graph showing median length of stay according to age (Fig. S2B in the Supplementary Appendix, available with the original article at NEJM.org). Although we could not identify a single group of infants in whom adrenaline had a significantly better effect than saline, the trend test indicated an increasing effect of adrenaline with increasing age.

Definitions for on-demand inhalation strategy and criteria for discharge from the hospital were requested by Ruiz-Contreras and GonzalezGranado. The physicians and nursing staffs were not provided with strict criteria but were instructed to use their best clinical judgment to decide when participants in the on-demand group should receive an inhalation. Factors to consider included both objective measures (e.g., oxygen saturation, respiratory rate, and clinical score) and subjective assessments (e.g., alertness and eating), as well as therapeutic response (with a better response leading to a higher priority of prescribing inhalation therapy) and timing (including the clustering of procedures that might cause stress in order to protect sleep and rest). Finding an infant ready for discharge from the hospital depended on objective measures of disease severity and the use of supportive care, social factors (parental skills and resources), 
geography (distance from home to hospital), and even hospital administrative factors (prioritization of patients in a crowded ward). Possible varying practice among hospitals is unlikely to have influenced the main results, because we found no significant hospital-treatment interaction.
Håvard Ove Skjerven, M.D.

Kai-Håkon Carlsen, M.D., Ph.D.

Karin C. Lødrup Carlsen, M.D., Ph.D.

Oslo University Hospital

Oslo, Norway

h.o.skjerven@medisin.uio.no

Since publication of their article, the authors report no further potential conflict of interest.

DOI: 10.1056/NEJMc1308964

\section{Antithrombotic Therapy and Invasive Procedures}

TO THE EDITOR: Baron et al. (May 30 issue) ${ }^{1}$ make important suggestions in their review article; however, we propose that quantitative assessment of iatrogenic bleeding hazards must be considered as well as thrombosis prevention. ${ }^{1} \mathrm{Al}-$ though $\mathrm{CHA}_{2} \mathrm{DS}_{2}-\mathrm{VASc}$ scoring for atrial fibrillation is mentioned, the Hypertension, Abnormal Renal/Liver Function, Stroke, Bleeding History or Predisposition, Labile INR, Elderly, Drugs/Alcohol Concomitantly (HAS-BLED) score for bleeding has also been validated. ${ }^{2}$ Both scores calculate estimated annual risks and benefits and hence can guide future therapy.

Among the diverse causes of major bleeding outcomes associated with antithrombotic agents are periprocedural, intracranial, and gastrointestinal causes. ${ }^{3}$ Although few therapies can treat and prevent the first two factors, data from a large, randomized trial show that proton-pump inhibitors are safe for concomitant use with antithrombotic agents. ${ }^{4}$ Given the shorter time frame in which medications are being withheld for procedures, the absolute thrombotic or bleeding risks can be overstated; however, bleeding (and its consequences) remains an important iatrogenic issue. Populations globally are also being treated increasingly with combinations of antithrombotic therapies and medications such as nonsteroidal antiinflammatory drugs (NSAIDs), which can intensify such bleeding risks. ${ }^{5}$ Hence, further quantitative research, including validation of cause-specific bleeding scores associated with antithrombotic agents, is paramount to guide clinical management.

Ajay M. Verma, M.R.C.P.

Kettering General Hospital Kettering, United Kingdom

Neeraj Bhala, M.R.C.P.

Queen Elizabeth Hospital Birmingham, United Kingdom nijbhala@doctors.org.uk
No potential conflict of interest relevant to this letter was reported.

1. Baron TH, Kamath PS, McBane RD. Management of antithrombotic therapy in patients undergoing invasive procedures. N Engl J Med 2013;368:2113-24.

2. Lip GY, Frison L, Halperin JL, Lane DA. Comparative validation of a novel risk score for predicting bleeding risk in anticoagulated patients with atrial fibrillation: the HAS-BLED (Hypertension, Abnormal Renal/Liver Function, Stroke, Bleeding History or Predisposition, Labile INR, Elderly, Drugs/Alcohol Concomitantly) score. J Am Coll Cardiol 2011;57:173-80.

3. Bhala N, Taggar JS, Rajasekhar P, Banerjee A. Anticipating and managing bleeding complications in patients with coronary stents who are receiving dual antiplatelet treatment. BMJ 2011; 343: $\mathrm{d} 4264$

4. Bhatt DL, Cryer BL, Contant CF, et al. Clopidogrel with or without omeprazole in coronary artery disease. N Engl J Med 2010;363:1909-17.

5. Hallas J, Dall M, Andries A, et al. Use of single and combined antithrombotic therapy and risk of serious upper gastrointestinal bleeding: population based case-control study. BMJ 2006;333:726.

DOI: $10.1056 /$ NEJMc1308259

TO THE EDITOR: The review article by Baron et al. does not address the clinical safety and efficacy of new antithrombotic agents in patients with cancer who are undergoing surgical procedures. A sizable number of patients with cancer undergo surgery or procedures with local or regional anesthesia. Trials of oral direct thrombin inhibitors and oral factor Xa inhibitors have enrolled less than $5 \%$ of patients with cancer. ${ }^{1}$ Because of a lack of data, the American Society of Clinical Oncology recommends against the use of new oral anticoagulants (for prevention and treatment) in patients with cancer. ${ }^{2}$ These patients also frequently require anesthesia to undergo long invasive procedures. The American Society of Regional Anesthesia and Pain Medicine recommends cautious use of these agents in patients undergoing neuraxial anesthesia. ${ }^{3}$ The lack of both efficacy data and an antidote for reversibility of bleeding should prompt clinicians to be cautious while administering the new anticoagulants in 